\title{
Reconfiguring the Relationship Between Intelligence Professionals and the Public: A First Step Towards Democratising New Zealand's National Security?
}

\section{Authors: Damian Rogers \& Shaun Mawdsley}

To cite this article: Rogers, D. \& Mawdsley, S. (2021). Reconfiguring the Relationship Between Intelligence Professionals and the Public: A First Step Towards Democratising New Zealand's National Security? National Security Journal. Published 29 September 2021. doi:10.36878/nsj20210929.02

To link to this article: https://doi.org/10.36878/nsj20210929.02

View CrossRef data: https://search.crossref.org/?q=10.36878\%2Fnsj20210929.02 


\title{
RECONFIGURING THE RELATIONSHIP BETWEEN INTELLIGENCE PROFESSIONALS AND THE PUBLIC: A FIRST STEP TOWARDS DEMOCRATISING NEW ZEALAND'S NATIONAL SECURITY?
}

\author{
Damien Rogers and Shaun Mawdsley
}

\begin{abstract}
The secrecy surrounding intelligence work has meant the relationship between New Zealand intelligence professionals and the public they serve has always been somewhat problematic. Over the past decade, leaks, scandals and a deadly act of terrorism have certainly not improved the public's trust and confidence in the New Zealand Security Intelligence Service and the Government Communications Security Bureau. While the Government has undertaken several measures to strengthen the credibility of those agencies, including initiating public inquiries and bolstering governance arrangements, its current approach is rather limited, has reached those limits and could now be counterproductive. In light of the recommendations made by the Royal Commission of Inquiry into the Terrorist Attack on Christchurch Mosques on 15 March 2019 to increase public involvement in New Zealand's counterterrorism effort, we argue that it is time for this problematic relationship between intelligence professionals and the public to be rethought and reconfigured. To that end, we identify several concrete actions that parliamentarians and university leaders could consider taking to actively support intelligence professionals as they foster a society of informed citizens and create new opportunities to bring national security matters into the heart of democracy's deliberative processes.
\end{abstract}

Keywords: terrorism; public inquiries; official secrecy; transparency; expertise

\footnotetext{
$1 \quad$ Damien Rogers is a Senior Lecturer in Politics and International Relations at Massey University, Auckland. Shaun Mawdsley is a PhD Candidate in History at the School of Humanities, Media and Creative Communication, Massey University, Auckland. This article draws on a larger research paper entitled "Turning the Dial from 'Social Licence' to 'Democratic Security': New Zealand's Intelligence and Security Agencies and the Case for an Informed Citizenry." Available on request: D.R.Rogers@massey.ac.nz.
} 


\section{Introduction}

It is an oft-cited but still lamentable fact of life that the politics of contemporary world affairs are violent and dangerous. Political violence is especially rife, with armed conflicts fought in faraway places, such as Nagorno-Karabakh in the Caucasus and Tigray in Ethiopia, the situation in Afghanistan remains uncertain and war continues in Syria. ${ }^{1}$ Mass atrocities unfold in distant locales, such as Cameroon, Myanmar and Yemen. ${ }^{2}$ Acts of terrorism threaten to spark life into the dying embers of the Global War on Terror by encouraging another wave of reactionary state-based violence by liberal democracies and authoritarian regimes alike. Closer to home, Brenton Tarrant, now serving a life sentence without the possibility of parole for attacking two mosques and killing fiftyone Muslims in Christchurch, New Zealand, on 15 March 2019, demonstrated that New Zealand's geographic remoteness from foreign theatres of conflict offers no shield from the harms associated with violent extremism. ${ }^{3}$ Ahamed Aathil Mohamed Samsudeen's knife attack at an Auckland supermarket on 3 September 2021 offers a stark and grisly reminder that the threat of terrorism remains. Danger, however, is not only found at the barrel of a gun or the edge of a knife's blade, but lurks, too, at the touch of a keyboard. Transformed as cybersecurity challenges, traditional forms of espionage, sabotage and subversion take on added complexity, scale and dynamism. There is no shortage of state and non-state actors with the capability and intent needed to undermine New Zealand's democratic institutions or unduly influence its democratic practices. ${ }^{4}$

Under these intense conditions of insecurity, New Zealanders need intelligence and security agencies that can coordinate with other government agencies to protect them from harms associated with various forms of political violence and to ensure the integrity of their democratic institutions. During the Global War on Terror, both the New Zealand Security Intelligence Service (NZSIS) and the Government Communications Security Bureau (GCSB) received appreciable increases in funding, ${ }^{5}$ enlarged their respective workforces, ${ }^{6}$ were granted an array of greater information-gathering and surveillance powers, ${ }^{7}$ and provided stronger secrecy provisions for their work. ${ }^{8}$ It is very difficult, however, for intelligence professionals to demonstrate to the New Zealand public how or why these agencies' recent growth enables the New Zealand Government to better prepare for routine as well as surprise or novel security challenges.

While the relationship between New Zealand intelligence professionals and the public they serve has always been somewhat problematic, due in large part to the veil of official secrecy that creates a widespread ignorance of intelligence work, the Government's adoption in 2011 of an expansive definition of national security deepens this divide. Obfuscating the distinction between external and internal security threats, or indeed what can be considered a threat, fashions the conditions in which New Zealand citizens and permanent residents can be considered a source of, or conduit for, serious danger. ${ }^{9}$ This broad definition positions intelligence professionals separately from, and at times 
antagonistically to, New Zealand citizens and permanent residents as some individuals and groups conduct unlawful and nefarious activities. Put simply, the insider group of 'us' as members of the New Zealand nation and the outsider group of 'them' as foreigners has the potential to become an insider group of intelligence professionals and an outsider group of the general public. ${ }^{10}$ We fear an effect of this estrangement may create a perception that intelligence work is becoming less about protecting all New Zealanders and more about predating upon some of them as a means of fortifying intelligence professionals' status. Building on several recommendations to increase public involvement in New Zealand's counterterrorism efforts made by the Royal Commission of Inquiry into the Terrorist Attack on Christchurch Mosques on 15 March 2019, we argue that now is a propitious moment to rethink and reconfigure this problematic relationship between intelligence professionals and the public.

While a flurry of academic work examines various aspects of New Zealand's counterterrorism effort in the aftermath of the 11 September 2001 attack on the United States of America ${ }^{11}$ and, more recently, in the wake of Tarrant's attack in Christchurch, ${ }^{12}$ academics have also produced useful studies concerning New Zealand's search for national security more broadly defined. ${ }^{13}$ The academic literature focusing specifically on New Zealand intelligence work has so far cast light on scandals and controversies, ${ }^{14}$ laws and governance arrangements, ${ }^{15}$ as well as organisational change and intelligence operations. ${ }^{16}$ However, this nascent field of New Zealand intelligence studies has not yet considered intelligence practitioners as a cadre of professionals, nor has it examined the important relationship between those professionals and the public they serve. We think this omission deserves to be remedied because the practices of intelligence work are, at heart, a social phenomenon. ${ }^{17}$ Taking a politico-sociological perspective on the study of intelligence also gives focus to the social (and sometimes transnational) dynamics informing intelligence work as well as to the social consequences of that work.

In what follows, we aim to fill that gap in the nascent literature by calling into question the relationship between New Zealand intelligence professionals and the public they serve. In our first section, we argue that this problematic relationship produces a widespread ignorance of intelligence work, and suggest that leaks, scandals and a deadly act of terrorism are factors that have suppressed the New Zealand public's trust and confidence in the NZSIS and the GCSB over the past decade. In our second section, we examine several measures that the New Zealand Government has so far undertaken to improve the credibility of those agencies, specifically commissioning public inquiries and organisational reviews, strengthening existing public accountability measures, and increasing the transparency of agencies' activities. But we find, in our third section, that this approach is rather limited because it ignores broader questions about the formational qualities of leadership of New Zealand's intelligence professionals, the type of support those professionals provide to the New Zealand Defence Force (NZDF) and the New Zealand Police, and their ongoing connection to US intelligence and security 
agencies. We suspect the current approach may even be counterproductive as it could generate concerns that collectively sustain a deep public unease about New Zealand intelligence work.

Our article aims to demonstrate the value of academic research on New Zealand intelligence work to intelligence professionals, security practitioners and their parliamentary masters. Academic freedom is vital not only for pure research that aims to advance collective understanding through the production of new knowledge, but also for applied research that speaks to communities of practice that lie beyond academia. ${ }^{18}$ Academic freedom is valuable because it enables an intellectually independent appraisal of New Zealand intelligence work, the surveillance apparatus underpinning that work, and the professional cultures and daily work practices of those employed within the intelligence and security agencies, though this value is not yet fully recognised by those committed to a whole-of-government approach to security. While we happily highlight the value of academic research, we are mindful that not everyone will appreciate our argument. This article, which tests conventional thinking and challenges received wisdom on the current relationship between New Zealand intelligence professionals and the public they serve, may prove unsettling for some individuals and groups within the profession. Nevertheless, taking our cue from John Battersby, Rhys Ball and Nick Nelson, who adopted a "critical approach, but [one] also designed to be constructive," ${ }^{19}$ we close out this article by arguing the time is ripe to rethink and reconfigure this problematic relationship before we identify several concrete actions that parliamentarians and university leaders could consider taking to actively support intelligence professionals as they foster a society of informed citizens and create opportunities to bring national security matters into the heart of democracy's deliberative process - where we think these important discussions and debates belong.

\section{Low public trust and confidence}

The official secrecy surrounding intelligence work has meant the relationship between New Zealand intelligence professionals and the public they serve has always been somewhat problematic. At the turn of the millennium, former New Zealand Prime Minister Sir Geoffrey Palmer explained that:

New Zealand has had security and intelligence agencies for many years...

The existence of these agencies is often severely criticised by New Zealanders, particularly on account of their secrecy. While there has been a more open attitude to the need for security and intelligence agencies in recent years, many feel that the agencies should be more open to public scrutiny than they are.

There is a contradiction here. The more that is known about the activities of the agencies, the less effective they are likely to be. Secrecy, particularly of the intelligence itself, is critical. Thus, the principles of open 
government and transparency that apply to so much of the New Zealand government today cannot, without qualification, apply to the security and intelligence agencies. ${ }^{20}$

The current minister responsible for New Zealand's intelligence and security agencies echoes this view. In his first official speech as minister responsible for the NZSIS and the GCSB, Hon. Andrew Little stated that " $[\mathrm{m}]$ uch of the effectiveness of [the intelligence and security agencies'] work depends on their information, their methods and their people not being exposed" and that "[n]o one can expect our security and intelligence agencies to disclose operational details, targets of their work, methods deployed or the nature of their intelligence gathering." ${ }^{21}$ While intelligence professionals need to operate in secret to be effective, the veil of official secrecy produces and entrenches a widespread ignorance of their work among the New Zealand public. This is also double-edged, however, because it hampers the efforts of intelligence professionals to demonstrate the value of their work to the public.

Several public opinion surveys conducted over the previous decade draw a portrait of New Zealanders as poorly informed about those intelligence and security agencies and their work: less than one respondent in ten could name both agencies for instance, and only a similar proportion of respondents thought the risk of a terrorist attack in New Zealand was 'great' or 'very great.' Notwithstanding their appreciation that New Zealand society had not been made safer after two decades of a Global War on Terror, most respondents to two surveys conducted in 2014 and in 2016 thought the NZSIS and the GCSB do a good job (though positive evaluations of the GCSB's performance decreased in 2016)..$^{22}$ Given the lack of relevant survey data and other empirical research, ascertaining the level of the public's trust and confidence in New Zealand's intelligence and security agencies at any point in time remains difficult. Nevertheless, the evidence which is readily-available indicates that New Zealanders' trust and confidence in the NZSIS and the GCSB has been low in recent years. Parliamentarians have publicly called for efforts "to restore public confidence in our intelligence operations." ${ }^{23}$ Political reporters echoed those calls. ${ }^{24}$ Furthermore, public servants have conceded that "public confidence in the agencies was at a low ebb following allegations of potentially illegal surveillance, which led to the Review of Compliance at the GCSB." ${ }^{25}$

Identifying the causes of any shift in public opinion also remains difficult without relevant survey data, but we think that leaks, scandals and a deadly act of terrorism have certainly not improved the public's trust and confidence in the NZSIS and the GCSB. Edward Snowden's unauthorised disclosure of classified material held by the United States National Security Agency introduced new material into the public domain that increased understanding of intelligence work. These disclosures raised international concern not only about information management systems and related security protocols that were intentionally breached, but also about the scale and reach of the Five Eyes surveillance network. ${ }^{26}$ Closer to home, Snowden's leaks drew unwelcome attention to 
the NZSIS and the GCSB - with tough questions asked about mass surveillance and intelligence-gathering in the South Pacific, both of which were sufficiently serious to become the subject of an investigation by the Inspector-General of Intelligence and Security (IGIS). ${ }^{27}$

GCSB's unlawful surveillance of Kim Dotcom, a German-Finnish entrepreneur with permanent resident status, is the most well-known scandal involving New Zealand intelligence professionals. It was subsequently revealed that the GCSB may have conducted unlawful surveillance of a further 55 cases involving 88 individuals in order to support law-enforcement agencies. ${ }^{28}$ Another scandal involved then-Director of the NZSIS, Dr Warren Tucker, and a briefing he provided to then-Leader of the Opposition, Phil Goff. ${ }^{29}$ The NZSIS provided information that was incomplete, inaccurate and misleading to a blogger named Cameron Slater, who claimed a close association to the Prime Minister and is the son of a former National Party President. Those disclosures resulted in unfair criticism of Goff by Slater, other commentators, and news reporters, providing the basis for certain public comments aimed to discredit Goff by the thenPrime Minister and Deputy Prime Minister during an election year. The NZSIS not only failed to clarify or correct the information they had disclosed after the impact of these errors became apparent, but also denied requests for the same information made by political reporters. ${ }^{30}$

Scandals embroiled parliamentarians too. In 2013, then-Prime Minister John Key admitted he intervened inappropriately in the selection process to fill the vacant post of the GCSB Director. ${ }^{31}$ Ian Fletcher, a family friend during Key's childhood, was appointed to the role in 2010 by Key on Rennie's recommendation after Key had nominated him. Earlier, Key misled the public over when he first became aware of Dotcom's existence. Key insisted that he had not heard of Dotcom until September 2012, though on a rare visit to Pipitea House Key received a GCSB briefing in February 2012 that included a photo of Dotcom. Key disputed this fact until a junior staff member who prepared the briefing insisted it took place: Key corrected the Hansard record in October 2012. ${ }^{32}$

Brenton Tarrant's killing of fifty-one Muslims at two Christchurch Mosques was a deadly act of terrorism that shook the public's confidence in the ability of New Zealand's intelligence and security agencies to protect them. The Royal Commission of Inquiry into the Terrorist Attack on Christchurch Mosques on 15 March 2019 (RCOI) found that the relevant agencies had not failed to share information and that none of those agencies failed to meet the expected standards of professionalism. However, the report revealed a disturbing picture of New Zealand's counter-terrorism efforts:

By the middle of the last decade, the subjects of intelligence and security and counter-terrorism had become politically and publically toxic. There was little political ownership. Public sector leadership was fragmented 
through a decentralized national security system with the Public sector agencies involved in the counter terrorism effort acting in ways which were only loosely coordinated..$^{33}$

Moreover, the RCOI revealed chilling insights into the attitudes held by some New Zealand intelligence professionals. According to testimony provided by members of the Muslim community here in New Zealand, concerns they expressed about their own safety were dismissed, sometimes routinely so, by intelligence professionals and security practitioners who treated cases as isolated acts and "not part of a wider concern about terrorism and violent extremism." ${ }^{34}$ New Zealand intelligence professionals and security practitioners presumably assess the many reports they receive from the public in terms of some risk framework. This assessment process may have led many to understand those same intelligence professionals as viewing New Zealand Muslims as a suspect community. ${ }^{35}$ These concerns were echoed at a mass hui by members of minority and marginalised groups. ${ }^{36}$

On balance, it seems implausible to us that the abovementioned leaks, scandals and deadly terror attack in Christchurch would have created a positive impression of the agencies over the past decade or so. We believe, instead, that each of these events played a role in perpetuating New Zealanders' low public trust and confidence in the NZSIS and the GCSB, even when scandals may not be entirely of their making. In so saying, we are mindful that, as a phrase "low public trust and confidence" could be used to shift the onus of the problem away from intelligence professionals and parliamentarians, and onto the public-at-large. We think the use of this phrase to place excessive blame on the New Zealand public for this state of affairs would be mischievous when the balance of power clearly lies in the hands of the executive and bureaucracy.

\section{Current responses}

The New Zealand Government responded to the public's low trust and confidence by commissioning public inquiries into, ${ }^{37}$ and several organisational reviews of, ${ }^{38} \mathrm{New}$ Zealand's intelligence and security agencies. Most consultants engaged to conduct these inquiries and reviews appear focused on enhancing the effectiveness and efficiency of organisational performance, thereby demonstrating the public value of the Government's ongoing investment. Most recommended strengthening the existing governance arrangements of the NZSIS and the GCSB while Kitteridge, Bushnell and Wilson, and Beatie suggested the public release of their reports was itself a useful act of transparency and could help restore public confidence in the agencies. Unlike the organisational reviews, parts of which remain classified, the reports from public inquiries were written with the public in mind. While the late Hon Sir Michael Cullen and Dame Patsy Reddy offered a new definition of national security, Doug Martin and Simon Mount, two consultants engaged to investigate the public services' use of private investigators, aimed 
to enact ethical limits to efforts expanding the utility of intelligence work. Only Justice Sir William Young and Jacqui Caine recommended action to promote collective understanding of intelligence work among New Zealand society.

The Government also responded by strengthening public accountability measures within the existing governance arrangements. While Parliament still reigns supreme, not all the roads to public accountability now lead to the Prime Minister. In 2014, a new ministerial portfolio for National Security and Intelligence was established and has been held by the Prime Minister. It is responsible for leading the national security system. The ministerial responsibility for the two intelligence and security agencies was shifted from the Prime Minister to another parliamentarian, currently Andrew Little. In contrast to the previous arrangement, where the Prime Minister essentially held him or herself to account, the Minister responsible for the NZSIS and the GCSB is now held accountable for the proper and efficient performance of agency functions by the House of Representatives through the Intelligence and Security Committee (ISC). However, that Minister is a serving member of the ISC, which is supposed to hold him or her to account. To avoid all perception of a conflict of interest, the Minister should be called before the Committee, rather than sit on it.

Building on the Inspector-General of Intelligence and Security Act 1996, the scope of IGIS's powers have been reconfigured to align with the intelligence and security agencies' new functions under the Intelligence and Security Act 2017. The powers now granted to IGIS are like those of a Royal Commission of Inquiry, and he or she can compel persons to answer questions, produce documents or give sworn evidence. The prohibition on inquiry into operationally sensitive matters, including those relating to intelligence collection, methods and sources, has also been removed. These powers are not unlimited, however. The Inspector-General cannot, for example, retrospectively declare warrants invalid where serious deficiencies are identified in those authorisations. Furthermore, the Inspector-General's powers are easily undermined when intelligence professionals refuse to cooperate. That occurred during a review, undertaken between 2015 and 2017, of the NZSIS's access and use of information held by the New Zealand Customs Service where the NZSIS was "reluctant to engage with [the IGIS] office on the substantive issues." 39

The Directors-General of the NZSIS and the GCSB have used their annual reports to the House of Representatives, which are a key public accountability document, to showcase their efforts towards greater transparency. In 2009, the NZSIS used its Annual Report to explain that it:

endeavored to be more open in interaction with the New Zealand public. The NZSIS' Director has spoken at a number of fora during the year under review, for example at Rotary Clubs and academic courses. We are aware that further work needs to be done on our website to enhance our 
interaction with the public. This work will be undertaken as resourcing allows. The NZSIS is committed to raising the level of public interaction, and is actively looking for other opportunities to meet our public stakeholders' expectations ${ }^{40}$

This approach was reiterated by acting GCSB Director Una Jagose when she used the GCSB's Annual Report for 2015 to explain that:

We have heard, and are responding to, public calls for greater transparency. That remains a focus for both GCSB and the [New Zealand Intelligence Community] more broadly. Transparency and openness are not entirely straight forward in the security environment but we remain committed to them as concepts underpinning our work. We have to ensure that we do not inadvertently increase our vulnerabilities to people who do not have New Zealand's best interests at heart by revealing our sources, methods or targets. We don't want people we are gathering intelligence on, or defending computer networks from, to know that we are looking at them or how we are doing that. We don't even want them to know what we are or are not capable of. Getting the balance between security and transparency right requires the independent oversight functions now embedded in the system. We are not a closed shop, setting our own standards, judging ourselves against them and saying "trust us." Far from it; we work under a rigorous authorising regime and we are the subject of significant, strong and independent oversight by the InspectorGeneral of Intelligence and Security, the Parliamentary Intelligence and Security Committee, the Ombudsman and the Privacy Commissioner. ${ }^{41}$

The NZSIS Annual Report for 2011 included a section entitled "Industry, Academia, and Community Outreach." It highlighted efforts at greater transparency ranging from producing a new booklet "An Introduction to NZSIS - How we contribute to New Zealand's National Security" to the Director of Security giving speeches to the Institute of Internal Auditors, the Victoria University Masters of Strategic Studies Programme on Intelligence, and the New Zealand Institute of Intelligence Professionals in Auckland, Wellington and Christchurch. The NZSIS Annual Report for 2016 explained that the Director-General of the NZSIS:

has made herself available for interviews and briefings with media and has spoken at a number of functions and conferences across the country.... [and] has spoken at a number of academic conferences, sits on the Strategic Advisory Board for the Centre of Defence and Security Studies for Massey University, has presented to students undertaking study in areas relating to national security and is working with the academic sector to identify opportunities for research. ${ }^{42}$ 
Building on the efforts of their predecessors, both Andrew Hampton and Rebecca Kitteridge deliver opening statements to the ISC, and have given public speeches, and occasional interviews to political reporters. ${ }^{43}$ From a cynical perspective, however, these efforts at increased transparency might be understood as a form of propaganda in the sense that propaganda is information distributed by a state to its own citizens as a means of encouraging public support for war, or as a form of public diplomacy, which is usually a foreign policy practice aimed at influencing a foreign audience. ${ }^{44}$

\section{A new public unease?}

The Government's current approach to addressing the question of public trust and confidence in its intelligence and security agencies is rather limited - and, in our judgement, has now reached those limits. Notwithstanding the durable veil of official secrecy, the partial and fragmented picture revealed by leaks and increased transparency indicates a formidable surveillance apparatus that underpins New Zealand intelligence work. We doubt that significant advances in technical sophistication and operational reach of this highly capable and intrusive apparatus can be offset by further increases in transparency or even stronger public accountability measures. There is a risk, moreover, that the current approach is counterproductive as a new public unease concerning intelligence work could emerge within New Zealand society. ${ }^{45}$ Despite changes to the governance arrangements that increase the public accountability of the agencies, and despite reviews and inquiries into their activities, we suspect this new unease will likely be sustained by wider concerns over the leadership of New Zealand's intelligence professionals, their close working relationship with the NZDF and the New Zealand Police, and their ongoing connection to foreign partners, especially United States' intelligence and security agencies.

It seems reasonable to us that New Zealanders have good cause to be concerned about the pedigree of leadership over the intelligence profession. ${ }^{46}$ During the Cold War, both agencies were led by former military professionals, but since the Global War on Terror career bureaucrats, with backgrounds in law and diplomacy, have been appointed to the key leadership roles. ${ }^{47}$ This shift in professional backgrounds aims, at least on its face, to mainstream intelligence work within the machinery of government and, in part, address the important question of public trust and confidence in the agencies. We think this point is especially acute in the present moment, given the highly credible leadership demonstrated by Dr Ashley Bloomfield in his role as chief executive of the Ministry of Health and New Zealand's Director-General of Health. We see Bloomfield's credibility as a leader of his profession built on his relevant academic qualifications and practitioner experience, including at a specialised United Nations agency, and his ability to communicate to the wider public through news media. 
It also seems reasonable to us that New Zealanders would be concerned about aspects of the close working relationship between the NZSIS and the GCSB on the one hand, and the NZDF and the New Zealand Police on the other hand. The lawful function empowering the intelligence and security agencies to co-operate with the military and the constabulary positions the NZSIS and the GCSB as close working partners to the only organisations in New Zealand authorised to use deadly force, rendering them force-enablers and force-multipliers. Concerns surrounding this close working relationship with the NZDF informed at least one IGIS report, ${ }^{48}$ and featured within the Inquiry into Operation Burnham, which examined serious allegations, which were later exonerated, that members of the New Zealand Special Air Service (NZSAS) intentionally killed civilians in Afghanistan. ${ }^{49}$ It is possible that some New Zealanders might share concerns over the NZSIS and the GCSB's relationship with the New Zealand Police, particularly after a series of armed raids in the Urewera mountains in October 2007 involved some 300 police officers, including members of the Armed Offenders Squad and the Special Tactics Group. Despite this significant manpower, Operation Eight seized 17 firearms at three properties in Ruatoki, 7 firearms at a property in Auckland and 1 firearm at a property in Whakatane and another during a search in Wellington, and some ammunition..$^{50}$ Only four of the seventeen individuals arrested were tried in Court and found guilty on firearms charges as the Solicitor-General, David Collins, declined to press charges under the Terrorism Suppression Act 2002, which was no longer fit for purpose. $^{51}$

It seems reasonable to us, moreover, that New Zealanders have cause to be concerned about the ongoing connection between New Zealand intelligence professionals and their foreign counterparts within the Five Eyes network, especially the US intelligence and security agencies after the US Senate Select Committee on Intelligence's Study of the Central Intelligence Agency's Detention and Interrogation Program documented the use of torture (prohibited under international law) and the existence of extraordinary rendition programmes. ${ }^{52}$ The CIA's use of drones to conduct assassinations in situations beyond those considered to be armed conflict is equally concerning. ${ }^{53}$ Such concerns are genuine and understandable, and have informed an inquiry undertaken by IGIS. ${ }^{54}$

\section{Time for a new approach?}

Rather than call for further inquiries and reviews into New Zealand's intelligence and security agencies, or for stronger public accountability, or for more transparency, we think the time is ripe for the current relationship between New Zealand intelligence professionals and the public they serve to be rethought and reconfigured. Establishing a Muslim Community Reference Group as a means of ensuring opportunities for Muslim communities to engage with their inquiry, the RCOI made several recommendations that sought to encourage a higher degree of public involvement in New Zealand's 
counterterrorism effort. These recommendations included establishing an advisory group on counter-terrorism, comprising representatives from communities, civil society, local government and the private sector, to offer advice to the Government on preventing people from engaging in extremism, violent extremism and terrorism. These recommendations also called on the Government to establish a programme to fund independent New Zealand-specific research on the causes of, and measures to prevent, violent extremism and terrorism. New Zealand has already taken important steps in this direction. As IGIS, Cheryl Gwyn established a reference group comprising individuals from beyond the public service to provide her office with advice on legal, social and security developments in New Zealand and overseas, inform her work programme and offer feedback on her performance. The Ministry of Defence consulted with the public, including academics, during the development of its Defence White Papers 2010 and 2016.

While these laudable steps are a good start, we believe more needs to be done before the NZSIS and the GCSB can expect to enjoy the public's trust and confidence. Everyday New Zealanders must acquire higher levels of awareness around the purpose, functions and powers of New Zealand's intelligence and security agencies before the public can grant informed consent to be surveilled by the state beyond times of crisis and states of emergency. Fostering a society of citizens capable of granting such consent is thus a necessary pre-condition for the agencies to obtain and hold a social license to operate. ${ }^{55} \mathrm{New}$ Zealanders will also need ongoing access to up-to-date and accurate relevant information to inform their discussion and debate. While annual reports delivered to the House of Representatives offer some transparency over New Zealand intelligence work, and reports published by oversight bodies, especially IGIS, demonstrate scrutiny of that work, these accountability documents need to be the object of much more public discussion and debate than is the case today. New Zealanders will also need to be more socially aware and politically literate too, to understand complex security matters, and require forums to deliberate within and conduits through which to express their views to those who hold executive and bureaucratic power within our democracy. We think this will help capture and convey the public's opinions, views and debates. This process requires a repositioning of national security matters to the heart of the, at times, messy deliberative processes that democracy entails.

In the remainder of this article, we take seriously the possibility of an informed citizenry becoming actively involved in democratic security practice - that is, the security of the people, by the people, for the people. There is not yet a consensus on the content and limits of democratic security. ${ }^{56}$ By democratic security practice, we mean that security work is undertaken for the people in the sense that New Zealanders are the objects of protection and not the subjects of state surveillance - a practice that is all too easy to embrace for many states; the people of New Zealand are made safe, in other words, from the multitudinous harms that accompany various forms of political violence and 
the integrity of our democratic institutions are ensured. We also mean that security work is undertaken by the people in this sense that New Zealand public servants involved in intelligence work should embrace the diverse views of New Zealand society, but not so that they can better infiltrate suspicious' minority communities and marginalised ethnic groups, but rather, so that they can better understand their concerns and sustain professional cultures, attitudes and everyday work practice that embody and reflect those found across New Zealand. Finally, we also mean that this security work is of the people in the sense that security activities are framed and enabled by regular, direct and meaningful public engagement with intelligence professionals and parliamentarians. (By democratic security practice, we do not mean a theory of liberal peace, whose proponents claim that increasing and intensifying interconnections among different markets reduces the risk of international armed conflict. Nor do we mean a theory of democratic peace, whose proponents claim that democracies are less likely to attack another democracy than are authoritarian regimes. ${ }^{57}$ )

Understood in this way, a commitment to democratic security would require intelligence professionals to do something more than: enhance the visibility of their high-level policies and public-facing strategies; openly share their interpretations of the law governing their conduct; publicly explain changes in their organisational design; and justify to parliamentarians the allocation of resources against their strategic and operational priorities. It would require intelligence professionals to do something more than engage in additional outreach activities with traditional stakeholders. Indeed, such a commitment behooves intelligence professionals to play a pro-active role in co-creating opportunities for dialogue and formats for engagement that enable and value differences of opinion, dissent, criticism and even critique - all of which are, of course, attributes of a vibrant liberal democracy. This vision of democratic security heralds a major shift from a whole-of-government to a whole-of-society approach to security matters. Intelligence professionals have the most important role to play in fostering an informed society of citizens, though parliamentarians have an important role to play too, as do the leaders of New Zealand universities.

\section{Intelligence Professionals}

Those who lead the NZSIS and the GCSB could more often respond positively to requests for interviews by academics and political reporters, and could better resource the parts of their agencies responsible for declassifying documents and fulfilling requests for official information made by journalists, academics and other members of the public. They could commission and publicly release their assessments on issues, trends and events impacting New Zealand's security, including along the lines of the Strategic Assessment released to the public by the then External Assessments Bureau in 2000. ${ }^{58}$ The agencies could fund more scholarships encouraging students to undertake courses in undergraduate and postgraduate security studies (broadly conceived) currently offered at New Zealand universities. They could establish a fund to provide for foreign aca- 
demics with an international reputation for research excellence in security studies to visit and tour New Zealand, address Parliament, consult with the ISC and give public lectures at each of New Zealand's universities. The agencies should also consider introducing a new output class - public engagement and capacity building - and then report annually to Parliament against their efforts.

When preparing for major organisational reviews, the Directors-General could ensure they appoint consultants who are intellectually independent and bona fide subject-matter experts. Former State Service Commissioners or former Secretaries of Foreign Affairs previously appointed to undertake organisational review were - notwithstanding their extensive public service experience - neither intellectually independent from the machinery and cultures of government, nor were they likely to seriously challenge conventional thinking on security matters. We think reviewers need to be bona fide subject-matter experts, credentialed with university qualifications, responsible for authoring a body of respected work on intelligence matters, and have this expertise recognised as such by other experts in the field. If that is not possible, then there ought to be an expectation on those consultants to engage meaningfully with those who do hold such expertise.

As intelligence professionals move from thinking about security in terms of a whole-of-government approach towards a more inclusive whole-of society approach, they will need to focus their efforts on fostering an informed society of citizens while guarding against creating an informing society; that is, a society of informers. We also see a need for attitudes held by intelligence professionals to shift away from viewing minority and marginalised groups as either 'suspect' or 'victim' communities.

\section{Parliamentarians}

Ministers and senior members of the opposition could play important supporting roles in fostering an informed society of citizens. The House of Representatives is the prime site where parliamentarians can model good debating practice that not only respects, but also values and encourages differences of opinion, dissent and criticism relating to intelligence and security matters. We think that debate on substantive issues relating to security - that is, what, exactly, is to be protected, how those objects are to be secured and where the limits of those securing efforts lie - could be better informed by an annual address on New Zealand security delivered by the Prime Minister. We also think that the intellectual quality of the current parliamentary debate on security matters could be improved by adding to, and strengthening, the conceptual tools used to make sense and explain such matters.

ISC members are especially important here. They need not only to be capable of engaging meaningfully on matters that fall within the expertise of intelligence professionals, but also be prepared to re-politicise issues that have previously been securitised. ${ }^{59} \mathrm{~A}$ 
useful starting point would be a much tighter definition of national security that focused on ensuring the integrity of our democratic institutions and protecting all New Zealanders from the harms associated with various forms of political violence.

Parliamentarians could empower the Inspector-General to examine all use of products and services provided by the NZSIS and/or the GCSB, as well as their sharing of any capabilities. In other words, IGIS's remit should include the NZDF and the New Zealand Police where the NZSIS and/or the GCSB enable, assist and support them in any way. IGIS should similarly examine the use and impact of these products, services and capabilities by members of the wider intelligence community including those agencies with responsibilities for regulating the flow of people, goods and services across New Zealand's international border or for ensuring compliance with regulatory regimes managing the extraction of natural resources found within New Zealand's Exclusive Economic Zone. Parliament should also empower the Inspector-General to examine the use of these products, services and capabilities by the National Assessment Bureau and the National Security Group with the Department of the Prime Minister and Cabinet. We see merit in including the offices of the Prime Minister and of the Leader of the Opposition within IGIS's scope because this would give New Zealanders good reason to believe intelligence professionals and their parliamentary masters who use intelligence operate lawfully and with propriety, though we do appreciate this has the potential to further politicise the selection of future Inspectors-General.

When planning for public inquiries, Ministers could appoint reviewers who possess subject-matter expertise. Cullen (a former Deputy Prime Minister and former Finance Minister) and Reddy (former lawyer and businesswoman) did not demonstrate a depth of understanding normally expected of any expert on security matters. The same must be said of Young (Supreme Court Judge) and Caine (diplomat), both appointed as members of the Royal Commission of Inquiry into the Terrorist Attack on Christchurch Mosques on 15 March 2019. If that is not possible, then there ought to be an expectation on those reviewers to engage meaningfully with those who do hold such expertise.

Parliamentarians could engage more frequently, and more intensely, with the public on security issues by hosting an annual public conference on New Zealand security at Parliament, and by holding town hall-styled meetings with their constituencies and in local communities.

\section{University Leaders}

Leaders of New Zealand universities who have institutional authority to commit resources can help foster an informed society of citizens too. Firstly, they can ensure that those academics who undertake independent research in the field of security studies within New Zealand universities are well placed to support both parliamentarians and intelligence professionals. We think there is plenty of scope for these specialists to build 
on their own individual research efforts, forge connections and establish networks with other academics with an interest in New Zealand's intelligence work, and to collaborate on major research projects that advance understanding of security. University leaders could, as a matter of strategic priority, club fund one or two of these major initiatives as a way of providing seed resourcing at the early stages of research design and to provide alternatives to established funding providers. University leaders will, however, need to guard intellectual independence against the desire for others to instrumentalise academic research efforts. ${ }^{60}$ This will be especially acute when academics are granted access to classified material on the condition that they undergo security clearances and their research is vetted before it is published or otherwise publicly released. ${ }^{61}$ The use of contracts to encourage policy-relevant research can, in some cases, fetter academic freedom and curb the contractor's intellectual independence. Sustained and serious differences in opinion and critiques of New Zealand's intelligence and security agencies must not be confused with, or conflated to, some act of treason..$^{62}$ Rather, dissent from and critique of authority is a symptom of a vibrant liberal democracy and ought to be championed as such, particularly when it seeks to fulfil the university's responsibility to act as society's critic and conscience. ${ }^{63}$

Academics whose teaching is informed by their research in security studies are similarly well placed to support both parliamentarians and public servants. We think there is scope for academics to leverage their own individual teaching efforts to co-design and co-deliver a set of professional short courses which aim to develop and enhance understanding of security matters by parliamentarians and their staff, public servants within agencies, as well as news media professionals who cover these issues.

Academics with expertise in security matters and who are employed by universities that have campuses located in New Zealand's main cities (Auckland, Hamilton, Wellington, Christchurch and Dunedin) and in the regions (Palmerston North) could coordinate their efforts to engage directly with the New Zealand public through public lectures given on university campuses and regular contributions to mainstream media. The aim here could be to build and enhance New Zealanders' political literacy in security matters - that is, the intellectual capacity, through an understanding of key concepts and history of, to comprehend complex and dynamic security issues - so that everyone may better engage in meaningful public discussion and actively participate in democratic processes if they so choose.

\section{Conclusion}

While the dynamics informing, and the consequences following from, the recent growth of New Zealand's security and intelligence agencies is not yet fully understood, intelligence professionals and their parliamentary masters are still to demonstrate how this growth better prepares New Zealanders for routine, surprise and novel security challenges. This is somewhat concerning as the surveillance apparatus underpinning 
intelligence work now focuses on New Zealanders, meaning intelligence professionals stand further apart from the public they serve. We have argued here that now is a propitious moment to reconfigure this problematic relationship so that important matters of national security are the subject of public debate and democratic deliberation. We think parliamentarians and university leaders have important roles to play in democratising New Zealand's national security by actively supporting intelligence professionals as they foster a society of informed citizens and create new opportunities for the public to participate in New Zealand's ongoing search for security. The extent to which New Zealanders will rise to the occasion and become involved remains to be seen, however.

1 Therese Pettersson, Garoun Engstrom, Margareta Sollonberg, Shawn Davies, Naer Hawach, Magnus Oberg, Aber Deniz \& Stina Hogbladh, "Organized Violence 1989-2020, with a special emphasis on Syria," Journal of Peace Research, 58:4 (2021), pp. 809-825.

2 Global Centre for Responsibility to Protect, R2P Monitor, 1 June 2021, Issue 57.

3 Robert Patman, "NZ still has important role in the global challenge of violent extremism," Stuff, 31 July 2021. See also John Battersby, "Security sector practitioner perceptions of the terror threat environment before the Christchurch attacks," Kotuitui: New Zealand Journal of Social Sciences Online, 15:2 (2020), pp. 295-309.

4 The New Zealand Government has so far only publicly named Russia and China as sources of cyberattacks in New Zealand while expressing concern about North Korea's cyber-related activities. See Government Communications Security Bureau, "Press Release: Malicious cyber activity attributed to Russia," https://www.gcsb.govt.nz/news/malicious-cyber-activity-attributed-to-russia/; Government Communications Security Bureau, "Press Release: Cyber campaign attributed to China" https://www. gcsb.govt.nz/news/cyber-campaign-attributed-to-china/; and Government Communications Security Bureau, "Press Release: New Zealand concerned at North Korean cyber activity" https://www.gcsb.govt. nz/news/media-release-new-zealand-concerned-at-north-korean-cyber-activity/.

5 According to the Department of the Prime Minister and Cabinet, the budget of the New Zealand Security Intelligence Service was $\$ 1.5 \mathrm{~m}$ in 2000/01 and the budget for the Government Communications Security Bureau was just over $\$ 20 \mathrm{~m}$, combining to $\$ 31.6 \mathrm{~m}$; see Department of the Prime Minister and Cabinet, Securing Our Nation's Safety: How New Zealand manages its security and intelligence agencies (Wellington, 2000). According to Annual Reports to the House of Representatives, the New Zealand Security Intelligence Service's expenditure in 2019/20 was $\$ 99.5 \mathrm{~m}$ and the Government Communications Security Bureau's was nearly $\$ 179 \mathrm{~m}$, combining to over $\$ 278 \mathrm{~m}$.

6 According to the Department of the Prime Minister and Cabinet, the New Zealand Security Intelligence Service employed 115 staff in 2000 whereas the Government Communication Security Bureau had about 220; see Department of the Prime Minister and Cabinet, Securing Our Nation's Safety: How New Zealand manages its security and intelligence agencies (Wellington, 2000). According to the Annual Reports to the House of Representatives, the New Zealand Security Intelligence Service employed about 367 staff in 2020 whereas the Government Communications Security Bureau employed 488.

$7 \quad$ See Part 5 of the Intelligence and Security Act 2017.

8 See Part 2 of the Telecommunications (Interception Capability and Security) Act 2013.

9 According to the Department of the Prime Minister and Cabinet, national security is "the condition which permits the citizens of a state to go about their daily business confidently free from fear and able to make the most of opportunities to advance their way of life. It encompasses the preparedness, protection and preservation of people, and of property and information, both tangible and intangible." See the Department of the Prime Minister and Cabinet, National Security Handbook (Wellington, 2016), p. 7; see also the Department of the Prime Minister and Cabinet, New Zealand's National Security System (Wellington, 2011), p. 3. 
10 This is what Bigo describes as a professional guild. See Didier Bigo, "Sociology of Transnational Guilds," International Political Sociology 10:4 (2016), pp. 398-416.

11 John Battersby, "Terror Where Terror is Not: Australian and New Zealand Terrorism Compared," Studies in Conflict and Terrorism, 41:1 (2017), pp. 59-76; Bethan Greener-Barcham, "Before September: A History of Counter-terrorism in New Zealand," Australian Journal of Political Science, 37:3 (2002), pp. 509-524; John Ip, “The Making of New Zealand's Foreign Fighter Legislation: Timely Response or Undue Hast?", Public Law Review, 27 (2016), pp. 181-202; Jeffrey A. Sluka “The Ruatoki Valley 'Anti-terrorism' Police Raids: Losing 'Hearts and Minds' in Te Urewera, Sites, 7:1 (2010), pp, 44-65; and David Small, "The uneasy relationship between national security and personal freedom: New Zealand and the 'War on Terror,"' International Journal of Law in Context, 7:4 (2011), pp. 467-486.

12 See, for instance, a special issue on the contexts of the Christchurch terror attacks in Kotuitui: New Zealand Journal of Social Sciences Online, 15:2 (2020). The Guest editors were Charles Crothers and Thomas O'Brien. See also John Battersby \& Rhys Ball, "Christchurch in the context of New Zealand terrorism and right wing extremism," Journal of Policing, Intelligence and Counter Terrorism, 14: 3 (2019): pp. 191-207; John Batterby, Rhys Ball \& Nick Nelson, "New Zealand's Counter-terrorism Strategy: A Critical Assessment," National Security Journal, 2:1 (2020); and John Ip, "Law's response to New Zealand's 'darkest of days," Common Law World Review, 50:1 (2021), pp. 21-37.

13 See, for instance: Nicholas Dynon, "Securing Public Places: New Zealand's Private Security Sector as a National Security Enabler," National Security Journal, 1:1 (2019), pp. 75-92; William Hoverd,

"The Changing New Zealand National Security Environment: New Threats, New Structures, and New Research," National Security Journal, 1:1 (2019), pp. 17-34; Terry Johanson, "Weapons of Mass Distraction: New Zealand's National Security System," Democracy and Security, 13:2 (2017), pp. 103-116; Suzanne Loughlin, "Towards a critical discourse analysis of New Zealand security policy in Afghanistan," Kotuitui: New Zealand Journal of Social Sciences Online, 13:2 (2018), pp. 271-284; Sophie Victoria Ann Richardson \& Nicolas Gilmour, The European Review of Organised Crime, 2:2 (2015), pp. 51-70; and Jason Young, "Seeking ontological security through the rise of China: New Zealand as a small trading nation," The Pacific Review, 30:4 (2017), pp.: 513-530. See also William Hoverd, Nick Nelson \& Carl Bradley (eds), New Zealand National Security: Challenges, trends and issues (Auckland, Massey University Press 2017).

14 See, for instance: Kathleen M Kuehn, "Framing mass surveillance; Analyzing New Zealand's media coverage of the early Snowden files," Journalism, 19:3 (2017), pp. 402-419; Kathleen Kuehn, The PostSnowden Era: Mass Surveillance and Privacy in New Zealand (Wellington: Bridget Williams Books, 2016); Darren Palmer \& Ian J Warren, "Global Policing and the case of Kim Dotcom" International Journal for Crime, Justice and Social Democracy, 2:3 (2014), pp. 105-119; and Robert G Patman \& Laura Southgate, "National security and surveillance: the public impact of the GCSB Amendment Bill and the Snowden revelations in New Zealand," Intelligence and National Security, 31:6 (2016), pp. 871-887. 15 See, for instance: Caitlin Macdonald, Rhys Ball \& William James Hoverd, "Playing Hide and Speak: Analyzing the Protected Disclosures Framework of the New Zealand Intelligence Community," International Journal of Intelligence and Counterintelligence, 33:2 (2020), pp. 248-277; Valarie Redmond, "I Spy with My Not So Little Eye: A Comparison of Surveillance law in the United States and New Zealand, Fordham International Law Journal, $37: 3$ (2014), pp.733-776; and James Whibley, "One Community, Many Agencies: Administrative Developments in New Zealand's Intelligence Services," Intelligence and National Security, 29:1 (2014), pp. 122-135.

16 See, for instance: Andrew D Brunatti, “The architecture of community: Intelligence community management in Australia, Canada and New Zealand," Public Policy and Administration, 28 (2013), pp. 119-143; Paul G Buchanan, "Foreign Policy Realignment, Issue Linkage and Institutional Lag: The Case of the New Zealand Intelligence Community," in New Zealand and the World: Past, Present and Future, eds. Robert G Patman Iati Iati \& Balazs Kiglics (Singapore: World Scientific, 2018), pp. 373-390;

Austin Gee \& Robert G. Patman, "Small state or minor power? New Zealand's Five Eyes Membership, intelligence reforms, and Wellington's response to China's growing pacific role," Intelligence and National Security, 36:1 (2021), pp. 34-50; Alexander Gillespie \& Claire Breen, "The Security Intelligence Agencies in New Zealand: evolution, challenges and progress," Intelligence and National Security 36:5 (2021), pp. 676-695; Jim Rolfe, "Intelligence, Accountability and New Zealand's National Security" in New Zealand and the World: Past, Present and Future, eds. Robert G Patman Iati Iati \& Balazs Kiglics (Singapore: World Scientific, 2018), pp. 359-371; Anthony L. Smith, "Informing the National Interest: The Role of Intelligence in New Zealand's Independent Foreign Policy," in New Zealand and the World: Past, Present and Future, eds. Robert G Patman Iati Iati \& Balazs Kiglics (Singapore: World Scientific, 2018), pp. 343-358; and Geoffrey R Weller. "Change and Development in the New Zealand Security and Intelligence Services," Journal of Conflict Studies 21:1 (2001). 
17 Hager Ben Jaffel, Alvina Hoffmann, Oliver Kearns \& Sebastian Larsson, "Collective Discussion: Toward Critical Approaches to Intelligence as a Social Phenomenon," International Political Sociology, 14:3 (2020), pp. 323-344.

18 Academic freedom is defined under Section 267 of the Education and Training Act 2020 as "the freedom of academic staff and students, within the law, to question and test received wisdom, to put forward new ideas and to state controversial or unpopular opinions" and "the freedom of academic staff and students to engage in research."

19 John Battersby, Rhys Ball \& Nick Nelson, "New Zealand's Counter-terrorism Strategy: A Critical Assessment," National Security Journal, 2:1 (2020).

20 Geffrey Palmer, "Security and Intelligence Services - Needs and Safeguards," Securing Our Nation's Safety: How New Zealand Manages its Security and Intelligence Agencies (Wellington: Department of the Prime Minister and Cabinet, 2000), p. 9.

21 Andrew Little, "Opening address to the Massey University National Security Conference 2018," Massey University, Albany, 5 April 2018.

22 Curia Market Research, "Security Issues Poll," November 2016; and Curia Market Research,

"Security Issues poll," October 2014; see also Horizon Poll, "Strong public backing for new surveillance powers, curbs to media freedoms," 26 November 2010; Horizon Poll, "Surveillance: 75\% want to know what the Government is doing," 22 April 2015; Horizon Research, "Summary: Surveillance by Government agencies," March 2015.

23 David Shearer, Open Letter to the Prime Minister Rt Hon John Key, 27 September 2012.

24 Vernon Small, "Inquiry into future of GCSB warranted," Dominion Post, 11 April 2013; and John Armstrong "GCSB trickery and deception revealed," New Zealand Herald, 11 April 2013.

25 Andrew Little, "Proactive release - Strategic Capability and Resourcing Review Report Back," 28 May 2019.

26 Michael Cullen \& Patsy Reddy, Intelligence and Security in a Free Society: Report of the First Independent Review of Intelligence and Security in New Zealand (Wellington, 2016), p. 24.

27 Cheryl Gwyn, Complaints arising from reports of Government Communications Security Bureau intelligence activity in relation to the South Pacific, 2009-2015 (Wellington: Office of the Inspector-General of Intelligence and Security, 2018). For further details, see Damien Rogers, "Snowden and GCSB: Illuminating neoliberal governmentality?" in Andrew Colarick, Julian Jang-Jaccard \& Anuradha Mathrani eds, Cyber Security and Policy: A Substantive Dialogue (Auckland: Massey University Press, 2017).

28 This surveillance directly contravened New Zealand law at the time, as S 14 of the Government Communications Security Bureau Act 2003 stated that "the Director, any employee of the Bureau, and any person acting on behalf of the Bureau must not authorise or do anything for the purpose of intercepting the private communications of a person who is a New Zealand citizen or a permanent resident of New Zealand." See Rebecca Kitteridge, Review of Compliance at the Government Communications Security Bureau (March 2013). For further details, see Damien Rogers, "Extraditing Kim Dotcom: a case for reforming New Zealand's intelligence community?" Kotuitui: New Zealand Journal of Social Science Online, 10:1 (2015), pp. 46-57.

29 Nicky Hager, Dirty Politics: How attack politics is poisoning New Zealand's political environment (Nelson: Craig Potton Publishing, 2014).

30 Cheryl Gwyn, Report into the release of information by the New Zealand Security Intelligence Service in July and August 2011 (Wellington: Office of the Inspector-General of Intelligence and Security, 2014). For further details, see Damien Rogers, "Intelligence and Security Act 2017: A Preliminary Critique," New Zealand Law Review 4 (2018), pp. 657-692.

31 Editorial, “Key 'had forgotten' call to Fletcher," 3 News, 3 April 2013; Editorial, "Key's role upsets former spy chief," New Zealand Herald, 4 April 2013; Andrea Vance, "Key met spy candidate for breakfast," Dominion Post, 24 April 2013; Andrea Vance, "Key forgets tip to friend over spy job," Stuff, 4 April 2013; and Grant Robertson "John Key right on one thing - he is clueless," press release, 16 April 2013.

32 Editorial, "Kim Dotcom sets off year of fireworks for politicians," New Zealand Herald, 27 December 2012; and John Key, "PM releases results of the GCSB file review," press release, 4 October 2002. For further details see Damien Rogers, "Intelligence and Security Act 2017: A Preliminary Critique," New Zealand Law Review 4 (2018), pp. 657-692.

33 Young and Caine, Summary of the Report of the Royal Commission of Inquiry into the terrorist attack on Christchurch masjidain on 15 March 2019, p. 15. 
34 Young and Caine, "Summary of Submissions," p. 43.

35 Young and Caine, "Summary of Submissions," especially "Chapter 5: What people told us about the national security system and countering violence," pp. 40-63.

36 TVNZ, "Muslim women tell counter-terrorism hui they don't trust authorities to keep them safe," OneNews, 16 June 2021.

37 Michael Cullen \& Patsy Reddy, Intelligence and Security in a Free Society: Report of the First Independent Review of Intelligence and Security in New Zealand (29 February 2016); and William Young \& Jacqui Caine, Report of the Royal Commission of Inquiry into the terrorist attack on Christchurch masjidain on 15 March 2019.

38 Sandi Beatie \& Geoff Dangerfield, Follow -up Review for the New Zealand Intelligence Community (2018); Peter Bushnell \& Gary Wilson, Review of the agencies in the core New Zealand Intelligence Community (Unclassified Summary) (2014); Rebecca Kitteridge, Review of Compliance at the Government Communications Security Bureau (2013); Doug Martin \& Simon Mount, Inquiry into the Use of External Security Consultants by Government Agencies, 2018; Simon Murdoch, Report to the States Services Commissioner: Intelligence Agencies Review (2009).

39 Cheryl Gwyn, Annual Report: For the year ended 30 June 2017 (Wellington: Office of the Inspector-General of Intelligence and Security, 2017), p. 16.

40 New Zealand Security Intelligence Service, Annual Report for the year ended 30 June 2009, p. 15, https://www.nzsis.govt.nz/assets/media/nzsis-ar09.pdf.

41 Government Communications Security Bureau, Annual Report for the year ended 30 June 2015, p. 5, https://www.nzsis.govt.nz/assets/media/nzsis-ar15.pdf.

42 New Zealand Security Intelligence Service, Annual Report for the year ended 2016, https://www. nzsis.govt.nz/assets/media/nzsis-ar16.pdf.

43 See, for instance, Andrew Hampton "Opening statement to the Intelligence and Security Committee," 21 March 2018; Rebecca Kitteridge, "Speech: Opening statement to the Intelligence and Security Committee," 20 February 2019; and "Director-General remarks: Select Committee Inquiry into the 2017 General Election and 2016 Local Election," 11 April 2019; see also Rebecca Kitteridge, "Speech: Understanding Intelligence" 18 September 2019.

44 Christine Schwobel-Patel, Marketing Global Justice: The Political Economy of International Criminal Law (Cambridge: Cambridge University Press, 2021).

45 We take the term 'unease' from Bigo, who sees it as a condition produced by security professionals to preserve their own status and ensure their ongoing access to resources. We use it differently here; namely, to signify the possibility of the public turning their attention to intelligence professionals and their work. See Didier Bigo, "Security and Immigration: Toward a Critique of the Governmentality of Unease," Alternatives 27 (2002), pp. 63-90.

46 This alludes to formational factors of leadership, such as professional experience, rather than the exercising of it.

47 The first four men to lead the NZSIS - Sir William Gilbert (1956-1976), Judge Paul Molineaux CMG (1976-1983), Lindsay Smith CMG CBE (1983-1991) and Don McIver CMG OBE (1991-1999) each served in the New Zealand Army. The move away from military men began with the appointment of Richard Woods, a career diplomat, to the role of Director of Security, NZSIS (1999-2006) and continued with the appointment of Rebecca Kitteridge to that role (2014 - cur). Kitteridge was formerly Secretary of the Cabinet and had spent periods of time as a lawyer in private practice and at the legal division of the Ministry of Foreign Affairs and Trade, and as Crown Counsel to the Cabinet Office. The first two Directors of the GCSB - Colin Hanson OBE (1977-1988) and Ray Parker (1988-1999) - had military backgrounds too. Sir Bruce Ferguson KNZM OBE AFC also had a distinguished military career, including as Chief of the Defence Force, before being appointed to the role (2006-2011). Jerry Mateparae, also Chief of the Defence Force, was Director of the GCSB briefly (February 2011-June 2011) before being appointed as Governor-General. Prior to his appointment to that role (2012-2015), Ian Fletcher was a former New Zealand diplomat before working in the British civil service on currency regulation, intellectual property rights issues, and in the Queensland State Government on commercial gas extraction matters. Simon Murdoch (acting twice between November 2010-February 2011 and July-December 2011), Una Jagose (acting between February 2015-February 2016) and Lisa Fong (acting between February 2016-April 2016) have temporarily filled that role too. Andrew Hampton (2016 - cur) is a career public servant. The outlier here is Dr Warren Tucker who served in the Army before joining the GCSB in 1982 and rose to the post of GCSB Director (1999-2006) before becoming Director of Security at the NZSIS. 
(2006-2014). Tucker remains the only New Zealand intelligence professional to have led a Security and Intelligence agency.

48 Madeliene Laracy made two recommendations in her report: firstly, "that in situations where the NZSIS and the GCSB are to provide support to military operations the intelligence agencies work to ensure there is inter-agency planning, in advance of that activity, which anticipates human rights risks, including how they will be identified and approached in the context of the collective inter-agency effort and the overarching government responsibilities [...and secondly that...] the agencies' review of the Joint Policy Statement on Human Rights Risk Management is expedited and pays specific attention to best practice, involving: (i) the threshold applied to the agencies to make decisions on sharing intelligence where there is a risk of human rights abuse; and (ii) the factors relevant to mitigation, especially the reliance that can safely be placed on factors such as assurances and caveats in inherently risky circumstances," p. 51.

49 Terence Arnold and Geoffrey Palmer, Report of the Government Inquiry into Operation Burnham (July 2020).

50 Independent Police Conduct Authority, Operation Eight: The Report of the Independent Police Conduct Authority, p. 14. Available at: https://www.ipca.govt.nz/site/publications-and-media/2013-reports-on-investigations/

51 Madeliene Laracy, GCSB and NZSIS in Afghanistan; see also Arnold and Palmer (2020).

52 Senate Select Committee on Intelligence's Study of the Central Intelligence Agency's Detention and Interrogation Program: Executive Summary (2014). See also Elspeth Guild, Didier Bigo \& Mark Gibney (eds), Extraordinary Rendition: Addressing the Challenges of Accountability (London and New York: Routledge, 2018).

53 Rebecca Sanders, Plausible Legality: Legal Culture and Political Imperative in the Global War of Terror (Oxford: Oxford University Press, 2018).

54 Cheryl Gywn, CIA detention and interrogation programme. Inquiry into possible New Zealand Intelligence and Security Agencies' engagement with the CIA detention and interrogation programme 2001-2009 (Wellington: Office of the Inspector-General of Intelligence and Security, 2019). Gywn found that "[t]he New Zealand intelligence and security agencies did not participate in the rendition and detention, or directly in the interrogation of detainees; nor were they complicit in the CIA's unlawful activities. The failing was one of omission, in not identifying that the CIA programme raised risks for their agencies and for the New Zealand Government, because of their close cooperation (including in Afghanistan) and ongoing intelligence relationships with the US intelligence and security agencies, including the CIA," p. 78.

55 Young and Caine define a social license to operate as "the ability of a business, organisation or government to do its work because it has the ongoing approval or acceptance of society to do so," p. 782. 56 Max Steuer, "Democratic Security" in Scott Romanuik \& Peter Marton, eds. The Palgrave Encyclopedia of Global Security Studies (Switzerland: Springer Nature, 2017). For an early attempt at explicating the term, see Robert C Johansen, "Real Security is Democratic Security," Alternatives, 16 (1991), pp. 209-242.

57 Roland Paris, At War's End: Building peace after civil conflict (Cambridge: Cambridge University Press, 2004), particularly chapter 2.

58 Mark Burton, "External Assessments Bureau - Strategic Assessment," 20 June 2000. Available at https://www.beehive.govt.nz/feature/external-assessments-bureau-strategic-assessment.

59 By 'securitisation,' I mean the process by which a routine matter of political contestation is transformed into a security issue by a speech act, or other discursive practice, made by a figure in possession of political authority, which is generally accepted by a broader audience. See Thierry Balzacq, "Constructivism and securitization studies" in Myriam Dunn Cavelty \& Victor Mauer (eds), The Routledge Handbook of Security Studies (London and New York: Routledge, 2012). See also Andrew W Neal, Security as Politics: Beyond the State of Exception (Edinburgh: University of Edinburgh, 2019); and Claudia Aradau "Security and the democratic scene: desecuritization and emancipation," Journal of International Relations and Development 7 (2004), pp. 388-413.

60 Section 267 of the Education and Training Act 2020 states that academic freedom means, among other things, "the freedom of academic staff and students, within the law, to question and test received wisdom, to put forward new ideas and to state controversial or unpopular opinions" and the "freedom to engage of academic staff and student to engage in research." See also Damien Rogers, "New Zealand Security Intellectuals: Critics or Courtesans?" in William Hoverd, Nick Nelson \& Carl Bradley eds. New Zealand National Security: Challenges, Trends and Issues (Auckland: Massey University Press). 


\section{NATIONAL SECURITY JOURNAL}

61 See comments made, for example, by Christopher Andrews, "Preface," Defend the Realm: The Authorised History of MI5 (New York: Alfred A. Knopf, 2009); and by Keith Jeffery, "Preface," The Secret History of MI6, 1909-1949 (New York: The Penguin Press, 2010).

62 William C Bradford, an assistant professor in law at West Point Military Academy, argued that legal scholars who were critical of the way in which the US Government conducted its Global War on Terrorism constituted a treasonous fifth column and should be targeted as enemy combatants. His employment there was short lived. See Spencer Ackerman, "West Point Professor calls on US military to target legal critics of war on terror," The Guardian, 29 August 2015.

63 Section 268(2)(d)I)(E) of the Education and Training Act 2020. 